\title{
Pramoninių LED šviestuvų fotonų srauto tankio poveikis agurkų daigams
}

\author{
Aistẻ Bagdonavičienė, \\ Julè Jankauskienè, \\ Aušra Brazaitytè, \\ Viktorija Vaštakaitė, \\ Pavelas Duchovskis \\ Lietuvos agrarinių ir mišku \\ mokslu centras, \\ Instituto al. 1 , \\ LT-58344 Akademija, Kédainiu r. \\ El. paštas: a.kasiuleviciute@lsdi.lt
}

Tyrimai atlikti LAMMC Sodininkystès ir daržininkystės instituto Augalų fiziologijos laboratorijos fitotrono komplekse ir instituto daigyno šiltnamyje. Darbo tikslas - parinkti naujų puslaidininkinių lempų fotonų srauto tankị auginat agurkų daigus šiltnamiuose ir fitotrone. Tyrimams naudotas agurkų hibridas 'Mandy' $\mathrm{F}_{1}$. Švitinta LED lempomis, kurios sudarytos iš violetinès 420-430 nm, mèlynos 460$470 \mathrm{~nm}$, oranžinès 610-615 nm, raudonos 620-630 nm ir 660-670 nm, baltos (mèlyna 400-500 nm + žalia 500-600 nm + raudona 600-700 nm) spalvos šviesą emituojančių diodų. Eksperimentų metu palaikytas skirtingas fotosintetiškai aktyvios spinduliuotès (FAS) fotonų srauto tankis (PPFD) - 150 ir $\sim 250 \mu \mathrm{mol} \mathrm{m}^{-2} \mathrm{~s}^{-1}$. Šiltnamyje agurkų daigai auginti po puslaidininkinėmis lempomis natūralaus apšvietimo fone. Fitotrono kamerose agurkų daigams apšviesti naudotos tik puslaidininkinès lempos. Palyginamieji daigai auginti po aukšto slègio natrio lempomis (SON-T Agro) $\left(\sim 150 \mu \mathrm{mol} \mathrm{m}{ }^{-2} \mathrm{~s}^{-1}\right)$. Atlikti apšvietimo tyrimai šiltnamyje ir fitotrone parodè, kad švitinimas naujomis puslaidininkinemis lempomis turèjo teigiamos ịtakos daigų biometriniams ir fitocheminiams rodikliams. Nustatyta, kad esant didesniam fotonų srauto tankiui daigai geba užauginti plačius lapus, sukaupti daugiau žalios ir sausos masès. Puslaidininkinių lempų šviesa skatino chlorofilų kaupimą daigų lapuose. Šiltnamyje labiausiai išsivystè daigai, augę po SON-T Agro lempomis. Techninès brandos tarpsniu jie pasiekė VI-VII organogenezės etapą. Fitotrone labiausiai išsivystė daigai, augę po puslaidininkinių lempų šviesa, jie pasiekè VI organogenezès etapą. Daigų fotosintezès intensyvumui didžiausios teigiamos itakos turejo $\sim 150 \mu \mathrm{mol} \mathrm{m}{ }^{-2} \mathrm{~s}^{-1}$ LED apšvietimo fotonų srauto tankis tiek šiltnamyje, tiek fitotrone.

Raktažodžiai: agurkai, daigai, fotosintetiniai pigmentai, fotosintezès intensyvumas, fotonų srauto tankis, šviesą emituojantys diodai (LED), žalia ir sausa masẻ

\section{IVADAS}

Daigų švitinimo optimizavimas turi svarbią reikšmę jų vèlesniam augimui šiltnamiuose ir nulemia augalų produktyvumą bei vaisių kokybę. Kietakūnio apšvietimo poveikis agurkų daigams LAMMC SDI Augalų fiziologijos laboratorijoje tyrinèjamas nuo 2007 m. (Urbonavičiūtè ir kt.; 2008; Brazaityté et al., 2009; Duchovskis ir kt., 2013). Nustatyti pagrindiniai šviesos poveikio augalams dèsningumai bei sukurtos iqvairios paskirties puslaidininkinès lempos (Bliznikas et al., 2004; 2009; Žukauskas, Duchovskis, 2009). Tačiau rinkoje atsiranda vis naujų puslaidininkinių lempų, pasižyminčių pažangiais techniniais sprendimais bei šviesos spektrinių komponenčių deriniais.

Manoma, kad raudona ir mèlyna šviesa yra pagrindinès apšvietimo spektro komponentès auginant agurkų daigus (Wenke, 2012). Raudona šviesa yra svarbi fotomorfogenezès procesams, skatina chlorofilo $b$ sintezę augaluose (Olle, Viršilè, 2013). Mèlyna šviesos komponente skatina žiotelių atsidarymą, chlorofilo a sintezę (Menard et al., 2006; Samuoliene et al., 2012) ir asimiliantuc perdavimą i kaupiančiuosius organus (Urbonavičiūtè ir kt., 2008). Bendras raudonos ir mèlynos šviesos poveikis vaidina svarbų vaidmeni - fotomorfogenezėje skatina žiotelių atsidarymą, chlorofilų sintezę, 
sausų medžiagų kaupimąsi (Matsuda et al., 2004; Menard et al., 2006; Trouwborst et al., 2010). Daigams augti vien raudonos ir mèlynos šviesos nepakanka (Wang et al., 2009). Oranžinè šviesa skatina agurkų augimą ir biomasės kaupimą, tačiau violetinè UV šviesa veikia priešingai - slopina. Balta šviesa didina agurkų lapų plotą, skatina biomasès kaupimą ir chlorofilų sintezę (Wang et al., 2009; Carvalho, Folta, 2014). Kitas labai svarbus šviesos parametras - fotonų srauto tankis. Manoma, kad auginant agurkų daigus jis turi būti ne mažesnis kaip $150 \mu \mathrm{mol} \mathrm{m}{ }^{-2} \mathrm{~s}^{-1}$ (Samuoliene et al., 2012).

Šiuo tyrimu siekiama išsiaiškinti galimybes integruoti naujas pramonines puslaidininkines lempas ị esamas agurkų daigų auginimo technologijas.

Darbo tikslas - parinkti naujų puslaidininkinių lempų fotonų srauto tankį auginant agurkų daigus šiltnamiuose ir fitotrone.

\section{METODAI IR SĄLYGOS}

Tyrimai atlikti $2014 \mathrm{~m}$. Lietuvos agrarinių ir miškų mokslų centro Sodininkystès ir daržininkystès instituto, Augalų fiziologijos laboratorijos fitotroniniame komplekse ir instituto daigyno šiltnamyje. Tyrimams parinktas ankstyvas partenokarpinis agurkų hibridas 'Mandy'.

Sąlygos. Daigai auginti polimeriniuose puodeliuose, pripildytuose durpių substrato (nurūgštintas, su trąšomis PG MIX (NPK 14-16-18; 1,3 kg/m³)).

Augalams apšviesti naudotos pramoninès puslaidininkinès lempos, sudarytos iš violetinès 420-430 nm (1 diodas), mèlynos 460-470 nm (2 diodai), oranžinès $610-615 \mathrm{~nm}$ (1 diodas), raudonos $620-630 \mathrm{~nm}$ (3 diodai) ir 660-670 nm (7 diodai), baltos (mèlyna 400-500 nm + žalia 500-600 nm + raudona 600-700 nm) (1 diodas) spalvos šviesos diodų.
Eksperimento šiltnamyje metu agurkų daigams taikytas skirtingo fotonų srauto tankio (PPFD) (150 ir $\left.250 \mu \mathrm{mol} \mathrm{m}{ }^{-2} \mathrm{~s}^{-1}\right)$ LED apšvietimas dienos šviesos fone. Atliekant eksperimentus uždarose fitotrono kamerose natūralus dienos apšvietimas eliminuotas, naudota tik 150 ir $200 \mu \mathrm{mol} \mathrm{m} \mathrm{m}^{-2} \mathrm{~s}^{-1}$ fotonu srauto tankio puslaidininkinių lempų skleidžiama šviesa. Abiejų eksperimentų metu palyginamajam augalų apšvietimui naudotos aukšto slègio natrio (SON-T

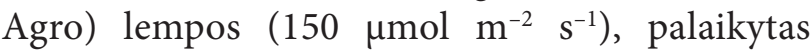
16 val. fotoperiodas.

Agurkų daigai šiltnamyje švitinti 25 dienas, fitotrono komplekse - 30 dienų. Augalai laistyti pagal poreiki.

Tyrimo metodai. Vertinant augalų augimo dinamiką matuotas hipokotilio ilgis ir skersmuo, tarpubamblių ilgis, visas augalo aukštis. Sausos medžiagos nustatytos išdžiovinus antžeminę ir šaknų masę $105 \pm 2{ }^{\circ} \mathrm{C}$ temperatūroje iki nekintamos masès. Augalų lapų plotas matuotas WinDias matuokliu (Delta-T Devices Ltd, UK). Chlorofilu indeksas lapuose nustatytas Dualex4 matuokliu (Force-A, Orsay, France). Pagal F. Kuperman (Kuperman, Rzhanova, 1985) metodiką nustatytas augalų organogenezès etapas. Fotosintezès intensyvumas daiguose matuotas nešiojamąja fotosintezès sistema LI-6400XT (LI-COR, USA).

Biometriniai ir fitocheminiai chlorofilai nustatyti atliekant dešimties augalų biologinius pakartojimus $(\mathrm{n}=10)$. Fotosintezès intensyvumas ịvertintas matuojant po 3 kiekvieno tiriamojo apšvietimo derinio augalus, 15 min. $(n=3)$.

Tyrimo metu tirtų veiksnių ittakos patikimumas ìvertintas dispersinès analizès metodu ANOVA skaičiuojant F kriterijų ir jo P reikšmę. Skaičiavimai atlikti naudojantis statistine programa STATISTICA 7.

1 lentelè. Apšvietimo spektro ir srauto deriniai agurkų daigų auginimo eksperimente

Table 1. Lighting combinations and photon flux densities of cucumber transplants growing in the experiment

\begin{tabular}{|c|c|c|c|c|}
\hline \multirow{2}{*}{$\begin{array}{l}\text { Variantas } \\
\text { Treatments }\end{array}$} & \multicolumn{3}{|c|}{$\begin{array}{l}\text { Fotonų srauto tankis (PPFD) } \mu \mathrm{mol} \mathrm{m} \mathrm{m}^{-2} \mathrm{~s}^{-1} \\
\text { Photosynthetic photon flux density (PPFD), } \mu \mathrm{mol} \mathrm{m} \mathrm{m}^{-2} \mathrm{~s}^{-1}\end{array}$} & \multirow{2}{*}{$\begin{array}{l}\text { Fotoperiodas } \\
\text { val. } \\
\text { Photoperiod, } h\end{array}$} \\
\hline & SON-T Agro & LED & LED & \\
\hline $\begin{array}{l}\text { Šiltnamis } \\
\text { Greenhouse }\end{array}$ & $\begin{array}{l}150+\text { dienos šviesa } \\
150+\text { day light }\end{array}$ & $\begin{array}{l}150+\text { dienos šviesa } \\
150+\text { day light }\end{array}$ & $\begin{array}{l}250+\text { dienos šviesa } \\
250+\text { day light }\end{array}$ & 16 \\
\hline $\begin{array}{l}\text { Fitotrono kamera } \\
\text { Phytotron chambers }\end{array}$ & 150 & 150 & 250 & 16 \\
\hline
\end{tabular}




\section{REZULTATAI IR JŲ APTARIMAS}

Šiltnamis. Priklausomai nuo apšvietimo derinio agurkų daigų antžeminè dalis vystèsi nevienodai. Nustatyta, kad aukščiausi augalai šiltnamyje užaugo po SON-T Agro lempomis, o žemiausi - po puslaidininkinemis lempomis, kur FAS srautas - $\sim 150 \mu \mathrm{mol} \mathrm{m} \mathrm{m}^{-2} \mathrm{~s}^{-1}$, tačiau gauti skirtumai nebuvo esminiai (2 lentelè). Po SON-T Agro lempomis augusių daigų hipokotilis buvo ištįsęs ir mažesnio skersmens. Daigų, augintų po LED

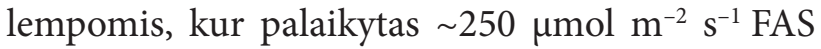
srautas, hipokotilis nebuvo išticsęs, jo skersmuo buvo didžiausias. Nepriklausomai nuo apšvietimo ir FAS srauto lapų skaičius buvo vienodas. Žalia ir sausa masẻ buvo didžiausia daigų, augintų po LED lempomis, kur FAS srauto tankis sieke $\sim 250 \mu \mathrm{mol} \mathrm{m}^{-2} \mathrm{~s}^{-1}$. Šio apšvietimo derinio teigiamas poveikis nustatytas ir daigų šaknų žaliai ir sausai masei bei chlorofilų indeksui. Labiausiai išsivystę buvo agurkų daigai, augę po SON-T Agro lempomis, jie pasiekè VI-VII organogenezès etapą (3 lentelè). Fotosintezès intensyvumui didžiausios teigiamos įtakos turejo $\sim 150 \mu \mathrm{mol} \mathrm{m}{ }^{-2} \mathrm{~s}^{-1} \mathrm{LED}$ apšvietimas (1pav.).

Fitotronas. Aukščiausi agurkų augalai fito-

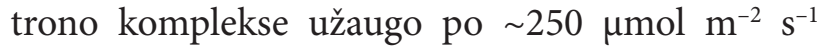
FAS, o žemiausi - po Son-T Agro lempomis (esminis skirtumas) (4 lentelè). Po SON-T Agro lempomis augusių daigų hipokotilio skersmuo
3 lentelè. Agurkų daigų žiedynų išsivystymas šiltnamyje esant skirtingam apšvietimo deriniui

Table 3. Development of cucumber transplants apexes in greenhouse under different lighting combinations

\begin{tabular}{|c|c|c|}
\hline 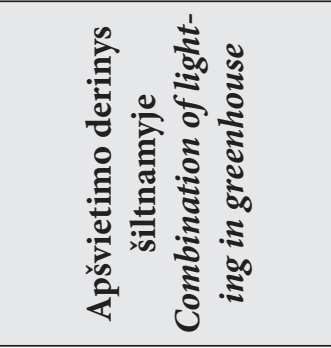 & 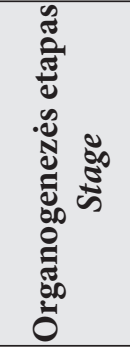 & 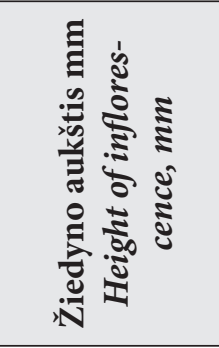 \\
\hline $\begin{array}{c}\text { SON-T Agro } \\
150 \mu \mathrm{mol} \mathrm{m}{ }^{-2} \mathrm{~s}^{-1}\end{array}$ & VI-VII & $0,81 \pm 0,050$ \\
\hline LED $150 \mu \mathrm{mol} \mathrm{m}^{-2} \mathrm{~s}^{-1}$ & VI & $0,75 \pm 0,006^{\star}$ \\
\hline LED $250 \mu \mathrm{mol} \mathrm{m}{ }^{-2} \mathrm{~s}^{-1}$ & VI & $0,73 \pm 0,040^{* *}$ \\
\hline
\end{tabular}

${ }^{*}$ patikimumas iki $\mathrm{P} \leq 0,05$; ${ }^{* *}$ patikimumas $\mathrm{P} \leq 0,01$;

${ }^{*}$ significant at $P \leq 0.05 ;{ }^{* *}$ significant at $P \leq 0.01$.

buvo toks pat kaip ir daigų, augintų apšviečiant $\sim 250 \mu \mathrm{mol} \mathrm{m}{ }^{-2} \mathrm{~s}^{-1} \mathrm{LED}$, tik jie buvo šiek tiek daugiau ištįsę. Skirtingas apšvietimas lapų skaičiui didelès įtakos neturejo. Augalų lapų plotas, žalia ir sausa masė buvo didžiausia daigų, augintų po $\sim 250 \mu \mathrm{mol} \mathrm{m}^{-2} \mathrm{~s}^{-1} \mathrm{LED}$, o mažiausia daigų, švitintų SON-T Agro lempomis. Agurkų daigų šaknų žalios ir sausos masès kaupimui teigiamą ịtaką turèjo $\sim 250 \mu \mathrm{mol} \mathrm{m} \mathrm{m}^{-2} \mathrm{~s}^{-1}$ LED apšvietimas. Visų daigu, augintų tirtuose variantuose, chlorofilų indeksas buvo panašus. Labiausiai išsivystę buvo

\section{2 lentelè. Biometriniai agurkų daigų rodikliai šiltnamyje esant skirtingam apšvietimo deriniui}

Table 2. Biometric characteristics of cucumber transplants growing in greenhouse under different lighting combinations

\begin{tabular}{|c|c|c|c|}
\hline \multirow{2}{*}{$\begin{array}{l}\text { Biometriniai rodikliai } \\
\text { Biometric parameters }\end{array}$} & \multicolumn{3}{|c|}{$\begin{array}{c}\text { Apšvietimo derinys šiltnamyje } \\
\text { Combination of lighting in greenhouse }\end{array}$} \\
\hline & $\begin{array}{c}\text { SON-T Agro } \\
150 \mu \mathrm{mol} \mathrm{m} \mathrm{m}^{-2} \mathrm{~s}^{-1}\end{array}$ & $\begin{array}{c}\text { LED } 150 \mu \mathrm{mol} \\
\mathrm{m}^{-2} \mathrm{~s}^{-1}\end{array}$ & $\begin{array}{c}\text { LED } 250 \mu \mathrm{mol} \\
\mathrm{m}^{-2} \mathrm{~s}^{-1}\end{array}$ \\
\hline Hipokotilio aukštis $\mathrm{cm} /$ Hypocotyl length, $\mathrm{cm}$ & $5,62 \pm 0,763$ & $4,70 \pm 0,515^{\star}$ & $4,06 \pm 0,462^{\star *}$ \\
\hline Hipokotilio skersmuo cm / Hypocotyl diameter, $\mathrm{cm}$ & $0,40 \pm 0,29$ & $0,53 \pm 0,024^{* *}$ & $0,55 \pm 0,022^{\star *}$ \\
\hline Antžeminis augalo aukštis $\mathrm{cm} /$ Height, $\mathrm{cm}$ & $17,52 \pm 2,764$ & $17,02 \pm 2,250$ & $17,12 \pm 2,465$ \\
\hline Lapų skaičius vnt. / Leaf number, units & $4,38 \pm 0,179$ & $4,26 \pm 0,114$ & $4,32 \pm 0,130$ \\
\hline Lapų plotas $\mathrm{cm}^{2} /$ Leaf area, $\mathrm{cm}^{2}$ & $655,54 \pm 55,940$ & $734,69 \pm 45,403$ & $788,56 \pm 29,131$ \\
\hline Antžeminè žalia masè g / Fresh weight, $g$ & $23,59 \pm 2,195$ & $27,258 \pm 1,966$ & $30,36 \pm 0,606^{*}$ \\
\hline Antžeminè sausa masè g / Dry weight, $g$ & $2,71 \pm 0,234$ & $2,99 \pm 0,224$ & $3,32 \pm 0,099^{*}$ \\
\hline Šaknų žalia masė g / Fresh weight, $g$ & $8,02 \pm 0,789$ & $8,65 \pm 0,697$ & $9,37 \pm 1,330$ \\
\hline Šaknų sausa masè g / Dry weight, $g$ & $0,41 \pm 0,042$ & $0,45 \pm 0,033$ & $0,45 \pm 0,055$ \\
\hline Chlorofilų indeksas / Chlorophyll index & $27,25 \pm 3,685$ & $26,68 \pm 2,87$ & $32,39 \pm 3,89^{*}$ \\
\hline
\end{tabular}

* patikimumas iki $\mathrm{P} \leq 0,05$; ${ }^{* *}$ patikimumas $\mathrm{P} \leq 0,01$;

${ }^{*}$ significant at $P \leq 0.05 ;{ }^{* *}$ significant at $P \leq 0.01$. 


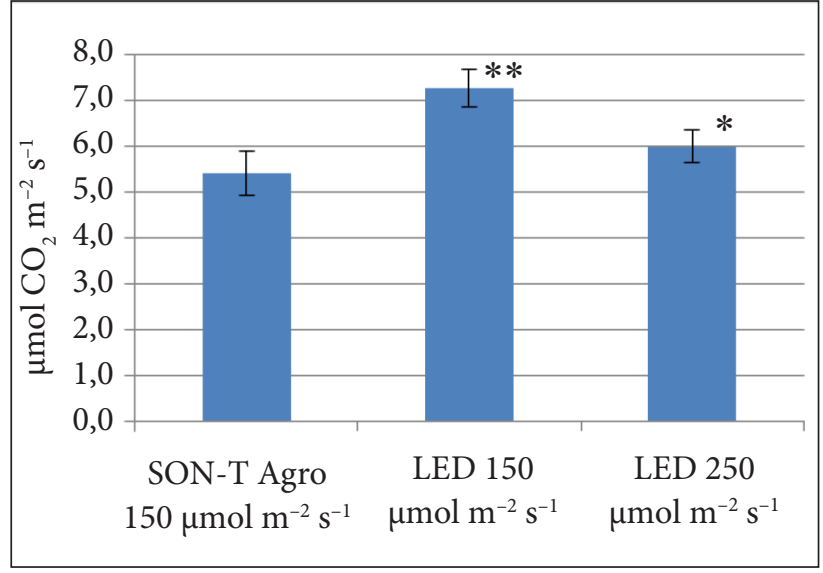

1 pav. Agurkų daigų fotosintezès intensyvumas $\mu \mathrm{mol}$ $\mathrm{CO}_{2} \mathrm{~m}^{-2} \mathrm{~s}^{-1}$ (šiltnamis)

Fig. 1. Photosynthetic rate in leaves of cucumber transplants, $4 \mathrm{~mol} \mathrm{CO} \mathrm{Cm}^{-2} \mathrm{~s}^{-1}$ (greenhouse)

* patikimumas iki $\mathrm{P} \leq 0,05$; ${ }^{* *}$ patikimumas $\mathrm{P} \leq 0,01$;

${ }^{*}$ significant at $P \leq 0.05 ;{ }^{* *}$ significant at $P \leq 0.01$.

agurkų daigai, augę po LED lempomis, jie pasiekè VI organogenezès etapą (5 lentelè). Fotosintezès intensyvumui didžiausios teigiamos įtakos turejjo $\sim 150 \mu \mathrm{mol} \mathrm{m}{ }^{-2} \mathrm{~s}^{-1}$ LED apšvietimas (esminis skirtumas) (2 pav.).

Aptarimas. Raudona, mèlyna, oranžinè ir balta spalva skatina agurkų lapų ploto didejimą, biomasès kaupimą, stimuliuoja antžeminès dalies augimą (Wang et al., 2009; Carvalho, Folta, 2014). Mūsų atliktų tyrimų duomenimis, daigų apšvieti-
5 lentelè. Agurkų daigų žiedynų išsivystymas fitotrone esant skirtingam apšvietimo deriniui

Table 5. Development of cucumber transplants apexes in phytotron under different lighting combinations

\begin{tabular}{|c|c|c|}
\hline 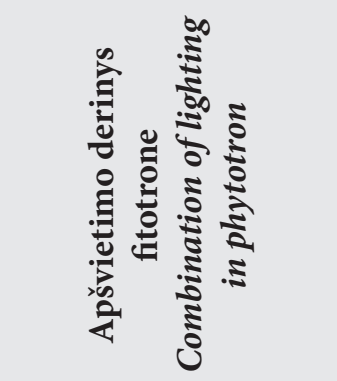 & 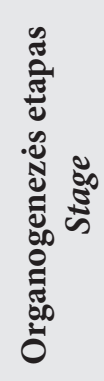 & 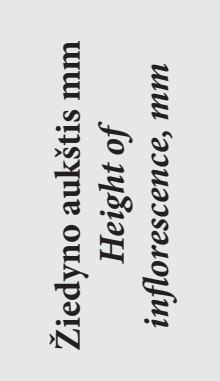 \\
\hline $\begin{array}{l}\text { SON-T Agro } \\
150 \mu \mathrm{mol} \mathrm{m}{ }^{-2} \mathrm{~s}^{-1}\end{array}$ & $\mathrm{~V}$ & $0,35 \pm 0,049$ \\
\hline LED $150 \mu \mathrm{mol} \mathrm{m}^{-2} \mathrm{~s}^{-1}$ & $\mathrm{~V}-\mathrm{VI}$ & $0,69 \pm 0,085^{\star *}$ \\
\hline LED $250 \mu \mathrm{mol} \mathrm{m}^{-2} \mathrm{~s}^{-1}$ & VI & $0,68 \pm 0,132^{\star *}$ \\
\hline
\end{tabular}

* patikimumas iki $\mathrm{P} \leq 0,05$; ${ }^{* *}$ patikimumas $\mathrm{P} \leq 0,01$;

${ }^{*}$ significant at $P \leq 0.05 ;{ }^{* *}$ significant at $P \leq 0.01$.

mas naujomis puslaidininkinemis lempomis turejo teigiamos įtakos lapų plotui, žalios ir sausos masių kaupimui šiltnamio ir fitotrono sąlygomis (2, 4 lentelè). Tirtas skirtingas šviesą emituojančių diodų fotosintetiškai aktyvios spinduliuotès srauto tankis (FAS) $\sim 150 \mu \mathrm{mol} \mathrm{m}{ }^{-2} \mathrm{~s}^{-1} \mathrm{~nm}$ ir $\sim 250 \mu \mathrm{mol} \mathrm{m} \mathrm{m}^{-2} \mathrm{~s}^{-1} \mathrm{~nm}$ parode, kad, didinant FAS, daigai geba formuoti didesnius lapus, kaupti didesnę antžeminę žalią ir sausą masę bei išauginti didesnę šaknų sistemą. İvairių autorių duomenimis, kietakūnio ap-

\section{4 lentelè. Biometriniai agurkų daigų rodikliai fitotrone esant skirtingam apšvietimo deriniui}

Table 4. Biometric characteristics of cucumber transplants growing in phytotron under different lighting combinations

\begin{tabular}{|c|c|c|c|}
\hline \multirow{2}{*}{$\begin{array}{l}\text { Biometriniai rodikliai } \\
\text { Biometric parameters }\end{array}$} & \multicolumn{3}{|c|}{$\begin{array}{l}\text { Apšvietimo derinys fitotrone } \\
\text { Combination of lighting in phytotron }\end{array}$} \\
\hline & 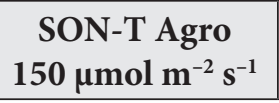 & $\begin{array}{c}\text { LED150 } \mu \mathrm{mol} \\
\mathrm{m}^{-2} \mathbf{s}^{-1}\end{array}$ & $\begin{array}{c}\text { LED } 250 \mu \mathrm{mol} \\
\mathrm{m}^{-2} \mathrm{~s}^{-1}\end{array}$ \\
\hline Hipokotilio aukštis cm / Hypocotyl length, $\mathrm{cm}$ & $2,86 \pm 0,730$ & $2,60 \pm 0,412$ & $2,72 \pm 0,618$ \\
\hline Hipokotilio skersmuo $\mathrm{cm} /$ Hypocotyl diameter, $\mathrm{cm}$ & $0,40 \pm 0,055$ & $0,36 \pm 0,055$ & $0,40 \pm 0,000$ \\
\hline Antžeminis aukštis $\mathrm{cm} /$ Height, $\mathrm{cm}$ & $12,48 \pm 0,950$ & $13,26 \pm 0,684$ & $18,00 \pm 0,485^{\star \star}$ \\
\hline Lapų skaičius vnt. / Leaf number, units & $6,10 \pm 0,548$ & $6,50 \pm 0,707$ & $6,90 \pm 0,894$ \\
\hline Lapų plotas $\mathrm{cm}^{2} /$ Leaf area, $\mathrm{cm}^{2}$ & $353,20 \pm 30,794$ & $417,74 \pm 34,169^{*}$ & $503,25 \pm 8,685^{\star \star}$ \\
\hline Antžeminè žalia masè g / Fresh weight, $g$ & $9,41 \pm 1,235$ & $11,01 \pm 0,889^{\star}$ & $16,16 \pm 0,052^{\star *}$ \\
\hline Antžeminè sausa masė g / Dry weight, $g$ & $1,12 \pm 0,201$ & $1,08 \pm 0,052$ & $2,00 \pm 0,179^{\star *}$ \\
\hline Šaknų žalia masė g / Fresh weight, $g$ & $2,19 \pm 0,612$ & $2,13 \pm 0,356$ & $3,83 \pm 0,537^{\star *}$ \\
\hline Šaknų sausa masè g / Dry weight, $g$ & $0,14 \pm 0,049$ & $0,13 \pm 0,022$ & $0,24 \pm 0,016^{* *}$ \\
\hline Chlorofilų indeksas / Chlorophyll index & $31,41 \pm 2,040$ & $31,41 \pm 2,040$ & $32,79 \pm 1,611$ \\
\hline
\end{tabular}

${ }^{*}$ patikimumas iki $\mathrm{P} \leq 0,05$; ${ }^{* *}$ patikimumas $\mathrm{P} \leq 0,01$;

${ }^{*}$ significant at $P \leq 0.05 ;{ }^{* *}$ significant at $P \leq 0.01$. 


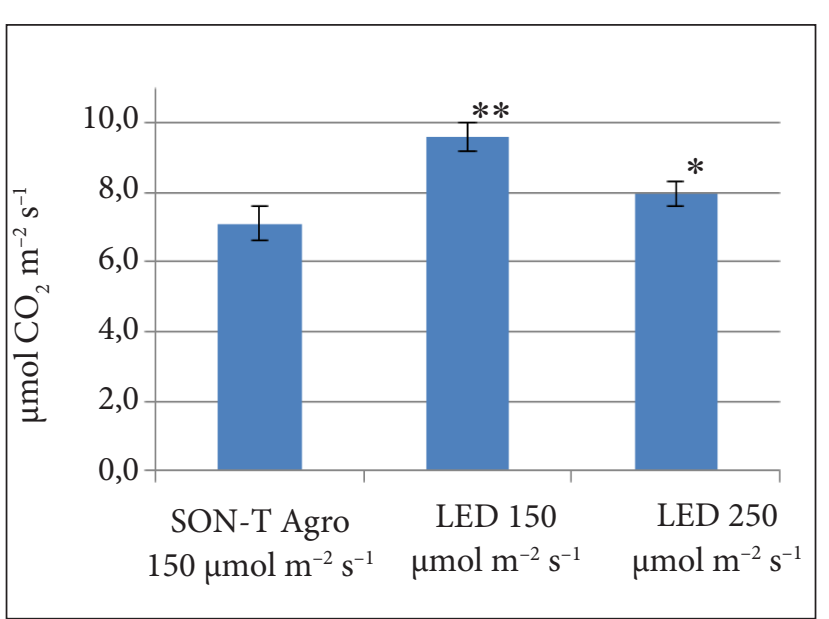

2 pav. Agurkų daigų fotosintezès intensyvumas $\mu \mathrm{mol}$ $\mathrm{CO}_{2} \mathrm{~m}^{-2} \mathrm{~s}^{-1}$ (fitotronas)

Fig. 2. Photosynthetic rate in leaves of cucumber transplants, $\mu \mathrm{mol} \mathrm{CO}_{2} \mathrm{~m}^{-2} \mathrm{~s}^{-1}$ (phytotron)

${ }^{*}$ patikimumas iki $\mathrm{P} \leq 0,05$; ${ }^{* *}$ patikimumas $\mathrm{P} \leq 0,01$;

* significant at $P \leq 0.05 ;{ }^{* *}$ significant at $P \leq 0.01$.

švietimo spektrą papildžius mèlynos, oranžinès, raudonos bei tolimosios raudonos bangų šviesos šviestukais, galima pagreitinti agurkų daigų auginimą ir sumažinti energijos sąnaudas (Brazaitytè et al., 2009). Raudoną šviesą emituojantys diodai didina sausų medžiagų kiekį antžeminèje augalo dalyje (Olle, Viršilè, 2013). Mèlyni $445 \mathrm{~nm}$ šviesą emituojantys diodai (LED) skatina fotosintezès pigmentų kaupimą agurkų daigų lapuose (Novičkovas et al., 2012; Kasiulevičiùtè, 2013). G. Trouwborst ir kitų autorių (2010) atlikti tyrimai su agurkais, augintais po aukšto slègio natrio lempomis kartu su raudonais ir mèlynais (santykiu 4:1) šviesą emituojančiais diodais, kai FAS srauto tankis $221 \mu \mathrm{mol} \mathrm{m} \mathrm{m}^{-2} \mathrm{~s}^{-1} \mathrm{~nm}$, parodè, kad toks apšvietimas skatino lapų ploto didejimą ir gerino fotosintezès sistemos parametrus, tačiau biomasès kaupimui ir tolimesniam derliaus kiekiui didelès ittakos neturejo.

A. Bagdonavičienès ir kitų autorių (2014) atlikti tyrimai fitotrone su agurkais parode, kad po raudonais ir mèlynais LED daigai antžeminèje dalyje ir šaknyse sukaupè esmingai daugiau žalios masès nei augę po SON-T Agro lempomis. SON-T Agro lempų šviesa létino agurkų daigų vystymąsi. Tai parodė ir mūsų gauti tyrimų duomenys (2, 3, 4, 5 lentelè).

Raudona, mèlyna ir balta spalva skatina chlorofilų sintezę agurkuose (Wang et al., 2009; Carvalho, Folta, 2014). Šiltnamyje ir fitotrone tirtos naujos puslaidininkinès lempos šviesa skatino chlorofilų kaupimą, tai užtikrina normalų fotosintezès procesą bei derliaus formavimą (1,2 pav.). Atlikti tyrimai su balta, raudona ir mèlyna LED šviesa auginant salotas atskleidè, kad raudona su mèlyna ir raudona su balta šviesa skatino žalios masès kaupimą, didino fotosintezès pigmentų kiekį (Wojciechowska et al., 2013). Mūsų tyrimų duomenimis, fotosintezès intensyvumui didžiausios teigiamos ịtakos turejo FAS $\sim 150 \mu \mathrm{mol} \mathrm{m} \mathrm{m}^{-2} \mathrm{~s}^{-1}$ švitinimas šviesą emituojančiais diodais tiek šiltnamyje, tiek fitotrone (1, 2 pav.). G. Trouwborst ir kitu autorių (2010) atlikti tyrimai su LED ir fotonų srauto tankiu auginant agurkus parode, kad normaliam fotosintezès intensyvumui užtikrinti FAS $300 \mu \mathrm{mol} \mathrm{m}{ }^{-2} \mathrm{~s}^{-1}$ neužtenka. Todèl tyrimai su skirtingu LED apšvietimo srautu gali būti tęsiami ateityje.

Priklausomai nuo apšvietimo ir augimo sąlygų, augalų organogenezè vyksta skirtingai. Mūsų duomenimis, daigyno šiltnamyje labiausiai išsivystė daigai, augę po SON-T Agro lempomis kartu su dienos šviesa, jie pasiekè VI-VII organogenezès etapą (3 lentelè). Fitotrono komplekse atlikto tyrimo rezultatai buvo priešingi: labiausiai išsivystè daigai, augę po naujų puslaidininkinių lempų šviesa, ir pasieké VI organogenezès etapą (5 lentelè). Kitų autorių duomenimis, skirtingas apšvietimas agurkų derliui désningo poveikio neturèjo (Carvalho, Folta, 2014), tačiau LED apšvietimas turejo ittakos žydejjimo ir derejjimo pradžioje (Brazaitytė et al., 2009; Brazaitytė ir kt., 2010).

\section{IŠVADOS}

1. Agurkų daigus švitinant šiltnamiuose puslaidininkinèmis lempomis suminis fotonų srauto

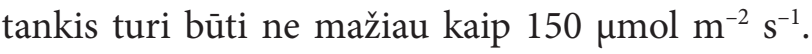
Tirtos naujos puslaidininkinès lempos užtikrina tokius parametrus ir yra pranašesnis už eksperimente naudotas aukšto slègio natrio lempas.

2. Auginant agurkų daigus šiltnamyje, papildant natūralų apšvietimą $\sim 250 \mu \mathrm{mol} \mathrm{m} \mathrm{m}^{-2} \mathrm{~s}^{-1}$ LED šviestuvų šviesa, augalai užauga kompaktiški ir labiau išsivystę, sukaupia daugiau žalios ir sausos masès, suformuoja gerą šaknų sistemą, sukaupia daugiau chlorofilų, tai užtikrina normalų fotosintezès procesą bei derliaus formavimą.

3. Auginant agurkų daigus fitotrono komplekse prie $\sim 250 \mu \mathrm{mol} \mathrm{m}{ }^{-2} \mathrm{~s}^{-1}$ LED šviestuvų, augalai užauga aukšti ir tvirti, sukaupia daugiau žalios ir 
sausos masès, išsivysto stipri šaknų sistema, augalui užtikrinamas normalus fotosintezès intensyvumas.

Gauta 20141023

Priimta 20150330

\section{LITERATŪRA}

1. Bagdonavičienė A., Jankauskienė J., Brazaitytė A., Duchovskis P., Novičkovas A., Dabašinskas L. 2014. Šviesą emituojančių diodų ir aukšto slėgio natrio lempų poveikis agurkų daigams auginant skirtinguose substratuose. Sodininkystè ir daržininkyste. Vol. 33(1-2). P. 61-73.

2. Bliznikas Z., Breivè K., Novičkovas A., Vitta P., Žukauskas A., Duchovskis P. 2009. Solid-state lamp for the improvement of nutritional quality of leafy vegetables. Electronics and Electrical Engineering. Vol. 8(96). P. 47-50.

3. Bliznikas Z., Breivė K., Tamulaitis G., Kurilčik G., Novičkovas A., Žukauskas A., Duchovskis P., Ulinskaitė R., Brazaitytė A., Šikšnianienė J. 2004. Puslaidininkinè lempa augalų fiziologiniams procesams tirti ir valdyti. Elektronika ir elektrotechnika. Vol. 56(7). P. 74-79.

4. Brazaitytė A., Duchovskis P., Urbonavičiūtė A., Samuolienė G., Jankauskienė J., Kasiulevičiūtè-Bonakèrè A., Bliznikas Z., Novičkovas A., Breivė K., Žukauskas A. 2009. The effect of light-emitting diodes lighting on cucumber transplants and after-effect on yield. Zemdirbyste-Agriculture. Vol. 96(3). P. 102-118.

5 Brazaitytė A., Duchovskis P., Viršilè A., Samuolienè G., Jankauskienė J., Novičkovas A. 2010. Agurkų daigų auginimas po halogeninèmis lempomis papildant spektrą $455 \mathrm{~nm}$ komponente. Sodininkyste ir daržininkystè. Vol. 29(2). P. 43-54.

6. Carvalho S. D., Folta K. M. 2014. Environmentally modified organisms - expanding genetic potential with light. Critical Reviews in Plant Sciences. Vol. 33(6). P. 486-508.

7. Duchovskis P., Brazaitytė A., Samuolienė G., Viršilè A., Miliauskienė J., Sakalauskienè S., Sirtautas R., Kasiulevičiūtè A. 2013. Augalų fiziologijos tyrimai agronominėms problemoms spręsti: ap̌̌valga. Sodininkystè ir daržininkystè. Vol. 32(3-4). P. 109128.

8. Kasiulevičiūtè A. 2013. Šviesos spektro sudèties ittaka agurkų (Cucumis sativus L.) daigų augimui ir fotosintezès pigmentu kiekiui. Sodininkyste ir Daržininkystè. Vol. 32(1/2). P. 67-76.
9. Kuperman F. M., Rzhanova E. I. 1985. Biologiya razvitiya kul'turnykh rasteniy. Vyshaya shkola, Moskva. T. 1. 192 s.

10. Matsuda R., Ohashi-Kaneko K., Fujiwara K., Goto E., Kurata K. 2004. Photosynthetic characteristics of rice leaves grown under red light with or without supplemental blue light. Plant \& Cell Physiology. Vol. 45(12). P. 1870-1874.

11. Menard C., Dorais M., Hovi T., Gosselin A. 2006. Developmental and physiological responses of tomato and cucumber to additional blue light. Acta Horticulturae. Vol. 711. P. 291-296.

12. Novičkovas A., Brazaitytė A., Duchovskis P., Jankauskienė J., Samuolienė G., Virsilè A., Sirtautas R., Bliznikas Z., Zukauskas A. 2012. Solid-state lamps (LEDS) for the short-wavelength supplementary lighting in greenhouses: experimental results with cucumber. Acta Horticulturae. Vol. 927. P. 723730.

13. Samuolienè G., Brazaitytė A., Duchovskis P., Viršile A., Jankauskienè J., Sirtautas R., Novičkovas A., Sakalauskienė S., Sakalauskaitė J. 2012. Cultivation of vegetable transplants using solid-state lamps for the short-wavelength supplementary lighting in greenhouses. Acta Horticulturae. Vol. 952. P. 885-892.

14. Trouwborst G., Oosterkamp J., Hogewoning S. W., Harbinson J., Van Ieperen W. 2010. The responses of light interception, photosynthesis and fruit yield of cucumber to LED-lighting within the canopy. Physiologia Plantarum. Vol. 138(3). P. 289-300.

15. Olle M., Viršile A. 2013. The effects of light-emitting diode lighting on greenhouse plant growth and quality. Agricultural and Food Science. Vol. 22(2). P. 223-234.

16. Urbonavičiūtė A., Samuolienè G., Brazaitytė A., Jankauskienè J., Kurilčik A., Duchovskis P., Žukauskas A. 2008. Augalų fotofiziologiniai tyrimai aukštosioms technologijoms. Sodininkyste ir daržininkystè. Vol. 27(3) P. 253-261.

17. Wang H., Gu M., Cui J., Shi K., Zhou Y., Yu J. 2009. Effects of light quality on $\mathrm{CO}_{2}$ assimilation, chlorophyll-fluorescence quenching, expression of Calvin cycle genes and carbohydrate accumulation in Cucumis sativus. Journal of Photochemistry and Photobiology B: Biology. Vol. 96(1) P. 30-37.

18. Wenke L. 2012. Light environmental management for artificial protected horticulture. Agrotechnology. Vol. 1. P. 101.

19. Wojciechowska R., Kołton A., Długosz-Grochowska O., Żupnik M., Grzesiak W. 2013. The effect of LED lighting on photosynthetic parameters and weight of lamb's lettuce (Valerianella locusta). Folia Horticulturae. Vol. 25(1). P. 41-47. 


\section{Aistė Bagdonavičienė, Julè Jankauskienė, Aušra Brazaitytè, Viktorija Vaštakaitè, Pavelas Duchovskis \\ INDUSTRIAL LIGHT-EMITTING DIODE LAMPS FOR GROWTH OF: (1) CUCUMBER TRANSPLANTS}

\section{Sum $m$ ary}

Experiments were carried out in the phytotron chambers of the Plant Physiology Laboratory and the greenhouse of the seed-plot of the Lithuanian Research Centre for Agriculture and Forestry. The aim of this study was to select the photon flux density of new solid-state lighting lamps for cucumber transplants growing in the greenhouses and the phytotron chambers under controlled environment growth conditions. Cucumber hybrid 'Mandy' F1 was chosen for investigation. Solid-state lighting lamps containing 420-430 nm (violet), 460-470 nm (blue), 610-615 nm (orange), 620-630 nm and 660-670 nm (red), and blue 400-500 nm + green 500$600 \mathrm{~nm}+$ red 600-700 nm (white) light-emitting diodes (LEDs) were used in the experiments. The generated photosynthetic photon flux density (PPFD) of each type of solidstate modules was $\sim 150$ and $\sim 250 \mu \mathrm{mol} \mathrm{m} \mathrm{m}^{-2} \mathrm{~s}^{-1}$. Cucumber transplants were grown in the greenhouse with a combination of natural light and LED light lamps. In the phytotron chambers only LED light lamps were used for cucumber transplants. As a reference group, transplants were grown under high-pressure sodium lamps (SON-T Agro), PPFD $\sim 150 \mu \mathrm{mol} \mathrm{m} \mathrm{m}^{-2} \mathrm{~s}^{-1}$. The lighting in the greenhouse and phytotron chambers has shown that irradiation of new LED lamps had a positive effect on the biometric and phytochemical parameters of cucumber transplants. Our investigations revealed that higher PPFD had a positive effect on the leaf area and fresh / dry weight of cucumber transplants. The cucumber transplants grown under the LED light lamps accumulated more chlorophyll in their leaves. The cucumber transplants grown under the SON-T Agro lamp were most developed in the greenhouse. They reached the stage of organogenesis VI-VII. In the phytotron chambers, most developed were the transplants grown under LED lamps, they reached the stage of organogenesis VI. LED PPFD $150 \mu \mathrm{mol} \mathrm{m}{ }^{-2} \mathrm{~s}^{-1}$ had the most positive impact on the photosynthetic rate in the greenhouse and phytotron chambers of cucumber transplants growing.

Key words: cucumber, transplants, photosynthetic pigments, photosynthetic rate, light-emitting diodes (LEDs), photosynthetic photon flux density, fresh and dry weight 